\title{
Crop Productivity Enhancement through Improved Technologies in North- South Transact of Bengaluru
}

\author{
A. Sathish ${ }^{1}$, B.N. Manjunath ${ }^{2}$ and Usha Kumari ${ }^{1}$ \\ ${ }^{1}$ Department of Soil Science and Agricultural chemistry, UAS, GKVK, Bengaluru, \\ Karnataka, India \\ ${ }^{2}$ Chr Hansen India Pvt Ltd, Mumbai, Maharashtra, India \\ *Corresponding author
}

\section{Keywords \\ Crop productivity, Fingermillet, Timely sowing, Weeding, Fertilizers application}

Article Info

Accepted:

12 April 2019

Available Online:

10 May 2019

\section{A B S T R A C T}

The crop productivity has been reached to the stagnation and there is no increase in the yield even at higher doses of fertilizers. The need of pacing up with the increase food demand with crop production is urgent for countries like India. To achieve this more focus is needed over the transition zone production system. In Bangalore north and south transact are at dynamic state in terms of production system and can be categorised as rural, urban and transition zone. The survey has been conducted in these areas regarding the present crop production practices and found unscientific practices were followed by the farmers and were convinced to follow the recommended practices of crop production. Total of 60 farmers have been selected who were growing finger millet, maize, field bean, tomato and brinjal, in both north and south transact villages and were availed the accurate amount of seeds of particular crops. They had adopted the scientific practices like timely sowing, weeding, fertilizers application, intercultural operations, efficient irrigation methods like drip irrigation and finally timely harvesting. The soil samples from the selected farmer's field have been collected and analysed and based upon the soil test results, fertilizers were weighed and distributed to each of the farmers to apply in time. The yield of the selected crops has recorded and found increase in yield in each of the selected crops compared to the control field. The increment of 6.85 to 20.83 per cent compared to control was observed in fingermillet, 3.2 to 21.2 per cent hike was observed in maize crop, 9.1 to 17.5 in field bean and $18.5 \%$ increment in brinjal crop have been observed in north transact. Similarly, in south transact the increment observed is 9.1 to $25.71 \%$ in fingermillet, 10 to $17.6 \%$ in field bean, 8.33 to 13.16 in maize, $8.9 \%$ increment in tomato and $10-11 \%$ in brinjal have been observed. Thus, adoption of scientific process of cultivation and application of fertilizers based upon the soil testing results increment in the yield of the crops.

\section{Introduction}

India's current population is 136.87 crores (Yearly change of $1.08 \%$ ). India is second most populated country in the world which is expected to overshoot China by 2021 .

\section{Bangalore comprises 12.34 million} population. The rural-urban interface is increasingly gaining importance in many cities around the world, but particularly in African and Asian countries, where it contributes significantly to food and fodder 
provision, job creation and other ecosystem services. In 2004-2005, the demand for cereals was $193 \times 10^{6} \mathrm{t}$, while in $2020-2021$, the projected demand will be $262 \times 10^{6} \mathrm{t}$ (Chand, 2007). To address the increased demand for food, agricultural programmes have doubled grain yields in irrigated land from $1.1 \mathrm{t} \mathrm{ha}^{-1}$ in 1960 to $2.5 \mathrm{t} \mathrm{ha}^{-1}$ in 2010. According to the Food and Agriculture Organization (FAO), urban and peri-urban farming supply food to 700 million city dwellers - about one quarter of the world's urban population (Marcotullio et al., 2008). Recent surveys indicate that urbanization almost inevitably triggers a rise in input intensity, changes towards new plant varieties with higher yield potential and harvest index and a move from subsistence crops (staple) to higher value vegetables for targeted consumer markets in order to use land and water more efficiently.Evidence also suggests that the opportunities to access profitable marketing channels depend on the level of education, technical knowledge / skills, and innovation of smallholder farmers. Soil fertility is a complex quality of soils that is closest to plant nutrient management. It is the component of overall soil productivity that deals with its available nutrient status, and its ability to provide nutrients out of its own reserves and through external applications for crop production. It combines several soil properties (biological, chemical and physical), all of which affect directly or indirectly nutrient dynamics and availability. Soil fertility quality is most commonly defined in terms of the ability of a soil to supply nutrients to crops (Watson et al., 2002), and it has been drastically affected by human activities (Bi et al., 2009; Huang et al., 2007; Jiang et al., 2006). Research indicated that soil fertility can be improved by appropriate agricultural practices such as tillage (Hussain et al., 1999; Kong et al., 2006), fertilizer application (Guo et al., 2010), incorporation of crop residues into soil ( $\mathrm{Bi}$ et al., 2009)
Conversely, inappropriate human activities such as imbalanced inorganic fertilizer application negatively affect soil fertility, which in turn, can influence the sustainability of agricultural systems (Stamatiadis et al., 1999; Vitousek et al., 2009). It was estimated that $40 \%$ of agricultural lands were affected by human induced land degradation (Oldeman et al., 1990).

The production efficiency and total yield of the crops have been reduced or stagnated even after the application of chemical fertilizer in tremendous amount under the intensive agriculture in recent years (Yadav and Meena, 2009).Keeping these points in view, the present study was conducted in North and South transact of Bengaluru during 2016-17 and 2017-18. Keeping these points in view, the present study was conducted in North \& South transact of bengaluru during 2016-2017 \& 2017-2018.

\section{Materials and Methods}

\section{Study area}

The present study had been conducted in the north and south transact of Bengaluru. Several villages have been selected for preliminary survey and further selection of farmers has been done based upon the crop production system. In North (Kodihalli, Gandarajapura, Karanalu, Kachehalli, Rajaghatta, T. Hoshalli, Thimmasandra, and Kudaregere) and South (Gulikamale, Taralu, Hosagabbadi, Halegabbadi and Kaggalahalli) and categorised into rural, urban and transition area (Fig. 1).

\section{Crop and cropping pattern identification}

A basic survey have been conducted in both transacts for the identification of present cropping system and cultivation practices adopted by the farmers through questionnaire 
in 120 farmers representing urban, rural and transition. Among the crops Finger millet was found to have highest coverage in area followed by tomato, maize and pigeon pea while in fruit crops grapes occupied more area followed by flowers in north (Table 1 and 2). In south transact mango cultivation was highest followed by guava and fingermillet crops. The lowest area coverage was by pigeon pea which account to 0.31 ha.

\section{Collection of soil samples}

Soil samples $(0-15 \mathrm{~cm})$ were collected at each of selected 60 farmers' field before and after the harvesting of crops during 2016-2017 and 2017-2018 which were geotagged.

\section{Analysis of soil samples}

The collected soil samples were air dried and processed for further analysis. These samples after processing were analysed for available nutrient content by standard analytical techniques. The $\mathrm{pH}$ and electrical conductivity of soil samples were determined following the method of Jackson (1973). The soil solution ratio1:2.5 were selected and $\mathrm{pH}$ and EC were estimated.

Available nitrogen was analyzed by potassium permanganate method of Subbiah and Asija (1956). Available phosphorus, available potassium, were determined as per the standard procedures (Olsen et al.,1954 and Bray's methods, Jackson, 1973). Available micronutrients ( $\mathrm{Fe}, \mathrm{Zn}, \mathrm{Cu}, \mathrm{Mn}$ ) from the samples were estimated using the AAS by following the protocol of Lindsay and Norvell (1978).

\section{Fertilizer recommendation}

Based on the soil test results of the farmers field fertilizers were recommended and fertilizers were weighed and distributed to the farmers after calculation.

\section{Results and Discussion}

\section{Soil chemical parameters}

The $\mathrm{pH}$ of the soil in north transact varied from 5.27 - 7.72 among the selected 31 farmers in the same region from different villages as well as having different cropping system. Similarly, under south transact the $\mathrm{pH}$ of the soil varied from 5.35- 8.13 through different selected villages and 29 selected farmers. The soil in north transact is acidic to slightly alkaline while in south transact it also consist more alkaline soil. The EC of south transact varied from $0.007-0.30 \mathrm{ds} / \mathrm{m}$ while in north transact it varied from $0.007-0.41 \mathrm{ds} / \mathrm{m}$ among the different farmer's field (Table 4 and 5). The low $\mathrm{pH}$ of the soil is due the acidic parent material and the tendency of $\mathrm{pH}$ towards slightly basic nature might be due to use of basic fertilizers as supported by Ram et al., 1999.

\section{Available nutrients}

Available nitrogen was low to medium (103.1-376.0 kg/ha), available phosphorus low to high (13-217 $\mathrm{kg} / \mathrm{ha})$ and available potassium was low in content $(48-207 \mathrm{~kg} / \mathrm{ha})$ (Table 5) in North transact. In North transact out of 31 farmer fields, $16 \%$ of soils were having low nitrogen and $84 \%$ having medium in nitrogen content. Whereas in case of phosphorus, $61 \%$ having medium and $39 \%$ were having high phosphorus content. Low potassium content was observed with $84 \%$ of soils and $16 \%$ soils having medium in potassium content. The lower availability of potassium is due to the negligence of the farmers to incorporate potassium while easy availability of phosphorus in market made the higher accumulation of the phosphorus in the soil. The micro nutrients were in sufficient quantity in most of the beneficiary fields. However, iron content ranges from 1.45 to $26.68 \mathrm{ppm}$, zinc is in the range of 0.20 to 9.10 
ppm, 0.34 to $2.05 \mathrm{ppm}$ of copper, 3.22 to $13.82 \mathrm{ppm}$ of manganese and boron ranges between 0.02 to $0.74 \mathrm{ppm}$ in the North transact while in south transact the range of micronutrients varied as iron 2.06-14.82, zinc 0.46 to 4.23 , copper 0.34 to 1.12 , manganese as 2.19 to 13.16 and boron varied as $0.04-0.46$ ppm.

At South transact, available nitrogen was low to medium (281 - $369 \mathrm{~kg} / \mathrm{ha})$, available phosphorus low to high (24 to 130 ), $\mathrm{K}_{2} \mathrm{O}$ was low to high (48-909 $\left.\mathrm{kg} \mathrm{ha}^{-1}\right)$, Exch. Na ranges from $0.20-0.99 \mathrm{cmol}(\mathrm{p}+) / \mathrm{kg}^{-1}$ and micronutrients were in medium range (Table 4).

In South transact Bengaluru out of 29 farmer fields all the soils are medium in nitrogen and none of soils have low or high. Whereas in case of phosphorus $81 \%$ having medium and $19 \%$ is having high phosphorus content. In case of potassium $56 \%$ of soils low in potassium, $33 \%$ soils having medium and 11 $\%$ soils have high potassium content. Excessive use of DAP without consideration of the soil test causes extra monetary burden on the farmers. Similar results have been founded by Ray et al., (2000), Milap et al., (2006) and Apoorva et al., (2010) and concluded that application of fertilizers based on the soil test results in higher yield in one side and showed improved soil properties in other side.

\section{Crop productivity}

The selected 60 farmers in north and south transact have been provided by fertilizer after the evaluation of soil samples and based on this soil test result fertilizers have been provided and found out major hike in the yield of farmers. The yield of different crops and their respective increase in yield over control plots were recorded (Table 2 and 3). At North rural, yield of finger millet varied from 17.3 to $35 \mathrm{q} / \mathrm{ha}$ and the $\%$ increase in yield ranged from 6.85 to 20.83 . Whereas maize crop yield was between 74.1 and 98.84 $\mathrm{q} /$ ha with increase in yield from 3.2 to 21.2 percent. In field bean and Brinjal yield was 12-32.5 and 395 q/ha with 9.1-17.5 and 18.5 $\%$ increase, respectively. Similarly, in case of Tomato it ranges from 444.5 to $617 \mathrm{q} / \mathrm{ha}$ with increase in yield of $9.52-20.0 \%$.

However at North transition, Tomato yield ranged from 370 to $691 \mathrm{q} /$ ha with increase in yield of 10 to $21.7 \%$ over control while in Brinjal it was between 345 to $494 \mathrm{q} / \mathrm{ha}$ with 12 to $17.6 \%$ increase in yield over control. Similar kind of response were observed within south transact where the crop yield ranged from 22.73 to $271.81 \mathrm{q} / \mathrm{ha}$ among crops. At south rural, yield of finger millet ranged between 23 to $40 \mathrm{q} / \mathrm{ha}$ with increase of 9.1 to $25.71 \%$ yield. Similarly, in field bean yield ranged between 24.7 to $27.6 \mathrm{~kg} / \mathrm{ha}$ with 10 to $17.6 \%$ increase over control. Tomato and Brinjal yields were 196 and 271-450 q/ha with 8.9 and $10-11 \%$ increase over control, respectively.

The crop yields of south transition region were recorded and their \% increase in yield over control plot was calculated. In case of Fingermillet, yield ranges from 22 to $36 \mathrm{q} / \mathrm{ha}$ with 10 to $22.7 \%$ increase over control. Similarly, in case of Maize and Avare 79-100 and 27-32.5 q/ha, yield was recorded respectively and the \% increase in yield over control was 7.89-14.3 and 11.5-17.9, respectively. Demonstration on technologies like soil test and crop requirement, mulching and drip irrigation in vegetable crops helps in getting higher yields in-addition to water saving there by enhancing the productivity also profit of farmer by getting "per drop more crop". Similar results were also reported by Singh et al., (2014); Ramakrishna et al., (2005) and Sharma and Singhal (2014). 
Table.1 Crops, cropping pattern and per cent to the total area of the North \& South transact of Bengaluru

\begin{tabular}{|c|c|c|c|c|c|c|c|c|c|c|c|}
\hline \multirow{2}{*}{\multicolumn{2}{|c|}{ Crop }} & \multicolumn{2}{|l|}{ Kharif } & \multicolumn{2}{|l|}{ Rabi } & \multicolumn{2}{|c|}{ Summer } & \multicolumn{2}{|c|}{$\begin{array}{l}\text { Grand } \\
\text { Total (ha) }\end{array}$} & \multicolumn{2}{|c|}{$\begin{array}{l}\% \text { to the } \\
\text { total area }\end{array}$} \\
\hline & & $\mathbf{N}$ & $\mathbf{S}$ & $\mathbf{N}$ & $\mathbf{S}$ & $\mathbf{N}$ & $\mathbf{S}$ & $\mathbf{N}$ & $\mathbf{S}$ & $\mathbf{N}$ & $\mathbf{S}$ \\
\hline \multirow{3}{*}{ Uू } & Fingermillet & 21.89 & 10.85 & - & 0.20 & - & - & $\begin{array}{l}21.8 \\
9\end{array}$ & 11.05 & $\begin{array}{l}45.5 \\
1\end{array}$ & 16.95 \\
\hline & Maize & 4.76 & 4.13 & 0.20 & - & 0.40 & 0.40 & 5.36 & 4.53 & $\begin{array}{l}11.1 \\
4\end{array}$ & 6.95 \\
\hline & Paddy & 0.40 & 1.92 & - & 0.40 & - & - & 0.40 & 2.32 & 0.83 & 3.56 \\
\hline \multirow{4}{*}{ 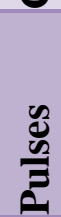 } & Pigeon pea & 1.42 & 0.20 & - & - & - & - & 1.42 & 0.20 & 2.95 & 0.31 \\
\hline & Field bean & 0.40 & - & - & - & - & - & 0.40 & - & 0.83 & \\
\hline & Peas & 0.40 & - & - & - & - & - & 0.40 & - & 0.83 & \\
\hline & Cowpea & - & 0.40 & & - & & - & & 0.40 & & 0.61 \\
\hline \multirow{11}{*}{ 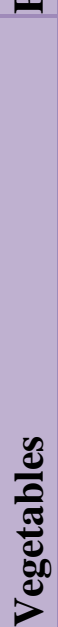 } & Tomato & 4.25 & 1.42 & 1.01 & 1.42 & 0.61 & - & 5.87 & 2.84 & $\begin{array}{l}12.2 \\
0\end{array}$ & 4.36 \\
\hline & Cauliflower & 1.42 & - & - & - & - & - & 1.42 & & 2.95 & - \\
\hline & Potato & 1.01 & - & - & - & - & - & 1.01 & & 2.10 & - \\
\hline & Capsicum & 1.01 & 0.40 & - & 0.40 & - & 0.40 & 1.01 & 1.20 & 2.10 & 1.84 \\
\hline & Bottle guard & 0.81 & - & - & - & - & - & 0.81 & & 1.68 & - \\
\hline & Brinjal & 0.81 & 0.04 & - & 0.20 & - & - & 0.81 & 0.24 & 1.68 & 0.37 \\
\hline & Carrot & 0.40 & - & 0.40 & - & - & - & 0.80 & & 1.66 & - \\
\hline & Ridge guard & 0.51 & 0.61 & - & 0.73 & - & - & 0.51 & 1.34 & 1.06 & 2.05 \\
\hline & Cabbage & 0.40 & - & - & - & - & - & 0.40 & - & 0.83 & - \\
\hline & Beet root & - & - & 0.40 & - & - & - & 0.40 & - & 0.83 & - \\
\hline & Cucumber & 0.20 & - & - & - & - & - & 0.20 & - & 0.42 & - \\
\hline \multirow{9}{*}{. } & Grapes & 2.14 & - & 0.52 & - & 0.52 & - & 3.18 & - & 6.61 & - \\
\hline & Mango & - & 5.26 & - & 5.26 & - & 5.26 & - & 15.78 & - & 24.20 \\
\hline & Guava & - & 4.05 & - & 4.05 & - & 4.05 & - & 12.15 & - & 18.63 \\
\hline & Jamun & - & 2.02 & - & 2.02 & - & 2.02 & - & 6.06 & - & 9.29 \\
\hline & Banana & - & 1.11 & - & 1.11 & - & 0.61 & - & 1.72 & - & 2.64 \\
\hline & Marigold & 1.21 & 0.20 & -- & - & - & - & 1.21 & 0.40 & $\begin{array}{l}2.5 \\
2\end{array}$ & 0.61 \\
\hline & Mulberry & - & 1.62 & - & 1.62 & & 1.61 & - & 4.86 & - & 7.45 \\
\hline & $\begin{array}{l}\text { Chrysanthe } \\
\text { mum }\end{array}$ & 0.40 & - & - & - & 0.2 & - & 0.60 & 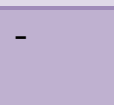 & 1.25 & 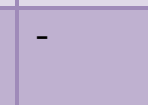 \\
\hline & $\begin{array}{l}\text { Grand } \\
\text { Total }\end{array}$ & $\begin{array}{l}43.84 \\
(91.14 \\
\%)\end{array}$ & $\begin{array}{l}34.35 \\
(52.69 \\
\%)\end{array}$ & $\begin{array}{l}2.53 \\
(5.26 \\
\%)\end{array}$ & $\begin{array}{l}16.91 \\
(25.9 \\
3)\end{array}$ & $\begin{array}{l}1.73 \\
(3.5 \\
9)\end{array}$ & $\begin{array}{l}13.95 \\
(21.3 \\
9)\end{array}$ & 48.1 & 65.21 & $\begin{array}{l}100 . \\
00\end{array}$ & $\begin{array}{l}100.0 \\
0\end{array}$ \\
\hline
\end{tabular}


Table. 2 Crop wise yield range $(\mathrm{kg} / \mathrm{ha})$ and $\%$ increase in yield at North rural and North transition

\begin{tabular}{|l|l|l|l|l|}
\hline \multirow{2}{*}{ Crop } & \multicolumn{2}{|c|}{ North rural } & \multicolumn{2}{c|}{ North transition } \\
\cline { 2 - 5 } & $\begin{array}{l}\text { Range } \\
\text { 2016-2018 } \\
\text { (Pooled data) } \\
\text { (q/ha) }\end{array}$ & \% increase & $\begin{array}{l}\text { Range } \\
\mathbf{2 0 1 6 - 2 0 1 8} \\
\text { (Pooled data) } \\
(\mathbf{q} / \mathbf{h a})\end{array}$ & \% increase \\
\hline Finger millet & $17.3-35$ & $6.85-20.83$ & 35 & 14.29 \\
\hline Maize- & $74.1-98.8$ & $3.2-21.2$ & - & - \\
\hline Field bean* & $12-32.5$ & $9.1-17.5$ & - & - \\
\hline Tomato & $444.5-617$ & $9.52-20$ & $370-691$ & $10.0-21.7$ \\
\hline Brinjal & $160-395$ & 18.5 & $345-494$ & $12-17.6$ \\
\hline
\end{tabular}

* Field bean - Green pod yield

Table.3 Crop wise yield range $(\mathrm{kg} / \mathrm{ha})$ and $\%$ increase in yield at South rural and South transition

\begin{tabular}{|l|l|l|l|l|}
\hline \multirow{2}{*}{ Crop } & \multicolumn{2}{|c|}{ South rural } & \multicolumn{2}{c|}{ South transition } \\
\cline { 2 - 5 } & $\begin{array}{l}\text { Range } \\
\text { 2016-2018 } \\
\text { (Pooled data) } \\
(\mathbf{q} / \text { ha) }\end{array}$ & $\begin{array}{l}\text { \% } \\
\text { Increase }\end{array}$ & $\begin{array}{l}\text { Range } \\
\mathbf{2 0 1 6 - 2 0 1 8} \\
\text { (Pooled data) } \\
(\mathbf{q} / \text { ha) }\end{array}$ & \\
\hline Finger millet & $23-40$ & $9.1-25.71$ & $22-36$ & $10-22.7$ \\
\hline Maize & $75-100$ & $8.33-13.16$ & $79-100$ & $7.89-14.3$ \\
\hline Field bean* & $24.7-27.6$ & $10-17.6$ & $27-32.5$ & $11.5-17.9$ \\
\hline Tomato & 196.0 & 8.9 & 550 & 13.64 \\
\hline Brinjal & $271-450$ & $10-11$ & - & - \\
\hline
\end{tabular}

* Fieldbean- Green pod yield

Table.4 Range of available nutrients along with physicochemical property in South transact Bengaluru

\begin{tabular}{|c|c|}
\hline Parameters & Range \\
\hline pH & $5.35-8.21$ \\
\hline $\mathrm{EC}(\mathrm{ds} / \mathrm{M})$ & $0.07-0.30$ \\
\hline Available Nitrogen $\left(\mathrm{kg} \mathrm{ha}^{-1}\right)$ & $281-369$ \\
\hline Available Phosphorus $\left(\mathrm{kg} \mathrm{ha}^{-1}\right)$ & $24-130$ \\
\hline Available Potassium(kg ha $\left.{ }^{-1}\right)$ & 48-909 \\
\hline Sodium cmol $(p+) k^{-1}$ & $0.20-0.99$ \\
\hline Available Iron (ppm) & $2.06-14.82$ \\
\hline Available copper (ppm) & $0.46-4.23$ \\
\hline Available Zinc (ppm) & $0.34-1.12$ \\
\hline Available Manganese(ppm) & $2.19-13.16$ \\
\hline Boron $(\mathbf{p p m})$ & $0.04-0.46$ \\
\hline
\end{tabular}


Table.5 Range of available nutrients along with physicochemical property in North transact Bengaluru

\begin{tabular}{|c|c|}
\hline Parameters & Range \\
\hline pH & $5.27-7.72$ \\
\hline EC (ds/M) & $0.07-0.41$ \\
\hline Available Nitrogen $\left(\mathbf{k g ~ h a}^{\mathbf{- 1}}\right)$ & $103-381$ \\
\hline Available Phosphorus $\left(\mathbf{k g ~ h a}^{\mathbf{- 1}}\right)$ & $13-217$ \\
\hline Available Potassium $\left(\mathbf{k g ~ h a}^{\mathbf{- 1}}\right)$ & $48-207$ \\
\hline Sodium cmol$(\mathbf{p}+) \mathbf{~ k g}^{-\mathbf{1}}$ & $0.23-0.59$ \\
\hline Available Iron $(\mathbf{p p m})$ & $1.45-26.68$ \\
\hline Available copper $(\mathbf{p p m})$ & $0.20-9.10$ \\
\hline Available Zinc $(\mathbf{p p m})$ & $0.34-2.05$ \\
\hline Available Manganese $(\mathbf{p p m})$ & $3.22-13.82$ \\
\hline Boron $(\mathbf{p p m})$ & $0.02-0.74$ \\
\hline
\end{tabular}

Fig.1 Location of farmer's field of North- South transact Bengaluru

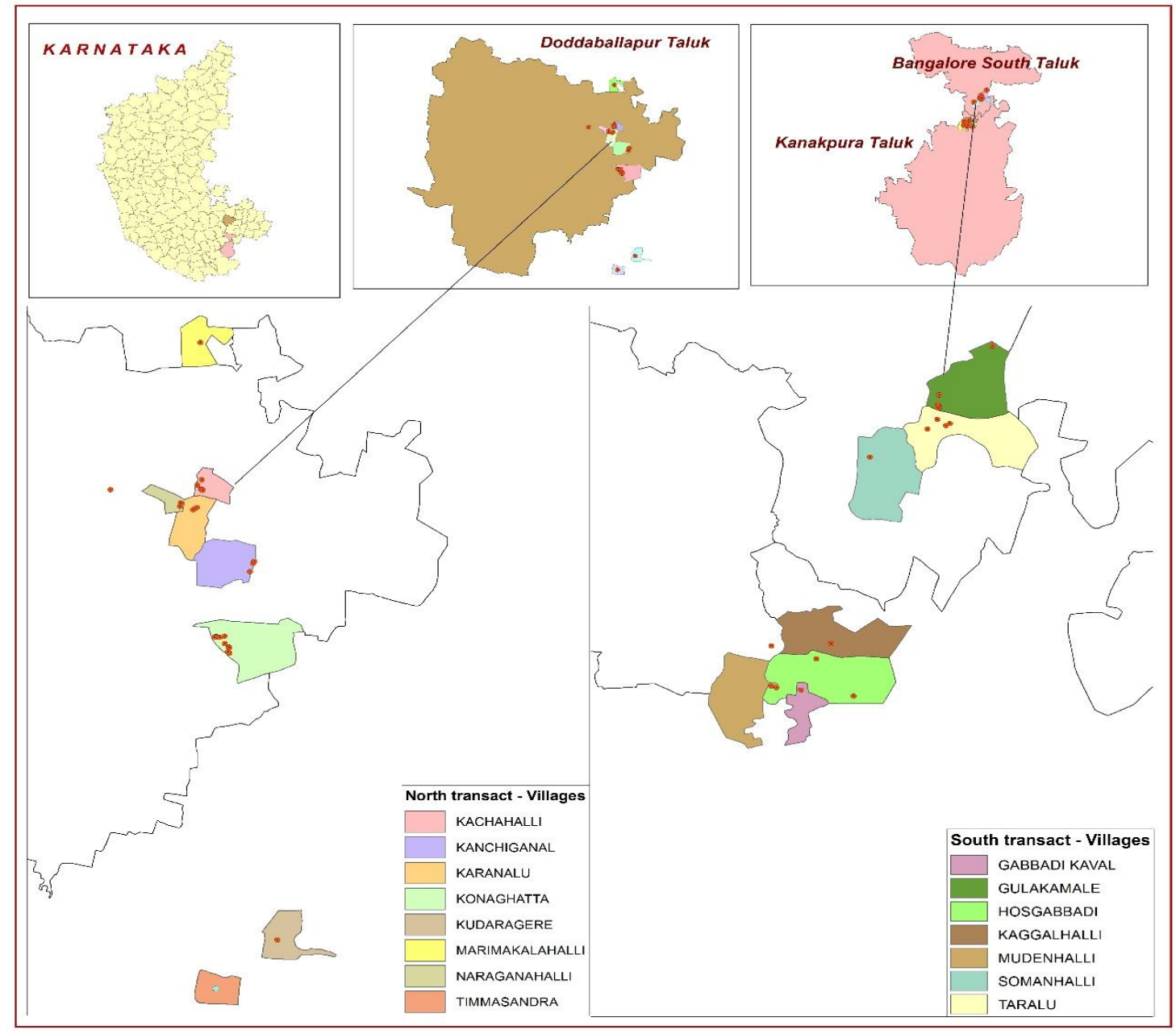


In conclusion, studying of crop production system prevailing in both transact revealed the dominant cropping system and crop production practices among farmers. The soil test based application of fertilizers raises the yield of the crops compared to the control fields. Among the different nutrients the application of potassium is least one while phosphorus has been applied in excess amount which raises the cost of cultivation for the farmers. So, the judicial use of fertilizers based on the soil fertility test and adoption of best management practices increased the yield of the crops.

\section{Acknowledgement}

The authors are grateful to Department of Biotechnology, Ministry of Science and Technology, Govt of India for offering funding to carry the project work.

\section{References}

Bi L, Zhang B, Liu G, Li Z, Liu Y, Ye C, Yu $X$, Lai $T$, Zhang $J$, Yin $J$, Liang $Y$ (2009) Long-term effects of organic amendments on the rice yields for double rice cropping systems in subtropical China. Agriculture, Ecosystem \& Environment. 129:534-54

Bray, R.H. and Kurtz, L.T., 1945, Determination of total organic and available forms of phosphorus in soils. Soil Science. 59: 39-45.

Chand, R. (2007) Demand for food grains. Economic and Political Weekly, 42, 10 13.

Dawe D, Dobermann A, Ladha JK, Yadav RL, Bao L, Gupta RK, Lal P, Panaullah G, Sariam O, Singh Y, Swarup A, Zhen QX (2003) Do organic amendments improve yield trends and profitability in intensive rice systems? Field Crop Research. 83: 191-213

Guo JH, Liu XJ, Zhang Y, Shen JL, HanWX,
ZhangWF, Christie P, Goulding KWT, Vitousek PM, Zhang FS (2010) Significant acidification in major Chinese croplands. Science 327:10081010

Huang B, Sun W, Zhao Y, Zhu J, Yang R, Zou Z, Ding F, Su J (2007) Temporal and spatial variability of soil organic matter and total nitrogen in an agricultural ecosystem as affected by farming practices. Geoderma 139:336345

Hussain I, Olson KR,WanderMM, Karlen DL (1999) Adaptation of soil quality indices and application to three tillage systems in southern Illinois. Soil Tillage \& Research. 50:237-249

Jackson, M.L. (1973) Soil chemical analysis. Prentice Hall of India Pvt. Ltd. New Delhi.

Jiang D, Hengsdijk H, Dai TB, de Boer W, Qi J, Cao WX (2006) Long-term effects of manure and inorganic fertilizers on yield and soil fertility for a winter wheat-maize system in Jiangsu, China. Pedosphere 16:25-32

Kong XB, Zhang FR, Wei Q, Xu Y, Hui JG (2006) Influence of land use change on soil nutrients in an intensive agricultural region of North China. Soil Tillage \& Research. 88:85-94

Lindsay, W.L. and Norvell, W.A. (1978) Development of a DTPA soil test for Zinc, iron, manganese and copper. Soil Science Society of American Journal, 42, 421-428.

Marcotullio, P.J., Braimoh, A.K. and Onishi, T., 2008, The impact of urbanization on soils. In Landuse and Soil Resources, A.K. Braimoh and P.L.G. Vlek (Eds), pp. 201-245. (The Netherlands: Springer).

Oldeman, L. R., R. T. A. Hakkeling and W. G. Sombroek. (1990). World Map of the Status of Human-Induced Soil Degradation: an Explanatory Note. 
Global Assessment of Soil Degradation GLASOD. ISRIC Series Working Paper and Preprint no. 90/7. Wageningen, The Netherlands.

Olsen, S.R., Cole, C.V., Watanabe, F.S. and Dean, L.A. (1954) Estimation of available phosphorus in soils by extraction with sodium bicarbonate. Circulation from United States Department of Agriculture. 939. USDA, Washington, D.C.

Ramakrishna, A., Wani, S.P., Rao, C.S. and Reddy, S.U. (2005) Increased chickpea yield and economic benefits by improved crop production technology in rainfed areas of Kurnool District of Andhra Pradesh India. Journal of SAT Agricultural Research 1 (1): 1-3.

Sharma, V.K. and Singhal, S.K. (2014) Validation of soil test based fertilizer prescriptions for targeted yield of pearl millet, rice, wheat and mustared at farmers, field. Annals of Plant and Soil Research 16 (4): 367-371.

Singh, Y.V. and Singh, S.K. (2014) Fertilizer prescription for targeted yield of rice (Oryaza sativa L var. Saryu-52) in and Inceptisol of Varanasi. Indian Journal of Ecology 41(2):282-285.
Stamatiadis S, Wernerb M, Buchanan M (1999) Field assessment of soil quality as affected by compost and fertilizer application in a broccoli field (San Benito County, California). Applied Soil Ecology. 12:217-225

Subbaiah, B.V. and Asija, G.L. (1956) A rapid procedure for the determination of available nitrogen in soil. Current Science. 25, 259-260.

Vitousek PM, Naylor R, Crews T, David MB, Drinkwater LE, Holland E, Johnes PJ, Katzenberger J, Martinelli LA, Matson PA, Nziguheba G, Ojima D, Palm CA, Robertson GP, Sanchez PA, Townsend AR, Zhang FS (2009) Nutrient Imbalances in Agricultural Development. Science, 324: 1519-1520

Watson CA, Atkinson D, Gosling P, Jackson LR, Rayns FW (2002) Managing soil fertility in organic farming systems. Soil Use Management. 18:239-247

Yadav, R.L and M.C. Meena. 2000. Available micronutrients status and their relationship with soil properties of Degana soil series of Rajasthan. Journal of Indian Society of Soil Science.57: 9092.

\section{How to cite this article:}

Sathish, A., B.N. Manjunath and Usha Kumari. 2019. Crop Productivity Enhancement through Improved Technologies in North- South Transact of Bengaluru. Int.J.Curr.Microbiol.App.Sci. 8(05): 1335-1343. doi: https://doi.org/10.20546/ijcmas.2019.805.152 